\title{
The Effect Analysis of Braden Scale on Pressure Ulcer in Community-Dwelling Older Adults
}

\author{
Desri Kristina Silalahi' ${ }^{1 *}$, Husneni Mukhtar ${ }^{2}$, Sheizi Prista Sari ${ }^{3}$, \\ Eka Afrima Sari ${ }^{4}$, and Dandi Trianta Barus ${ }^{5}$ \\ ${ }^{1,2}$ School of Electrical Enggineering, Telkom University \\ Jln. Terusan Buah Batu, Jawa Barat 40257, Indonesia \\ ${ }^{3,4}$ Faculty of Nursing, Universitas Padjadjaran \\ Jln. Raya Bandung Sumedang KM.21, Jawa Barat 45363, Indonesia \\ ${ }^{5}$ School of Computing, Telkom University \\ Jln. Terusan Buah Batu, Jawa Barat 40257, Indonesia \\ ${ }^{1}$ desrikristina@telkomuniversity.ac.id; ${ }^{2}$ husneni.mukhtar@telkomuniversity.ac.id; \\ ${ }^{3}$ S.sari@maastrichtuniversity.nl; ${ }^{4}$ e.afrima@unpad.ac.id; ${ }^{5}$ dandibaroes88@gmail.com
}

Received: $19^{\text {th }}$ January 2020/ Revised: $13^{\text {th }}$ April 2020/ Accepted: $2^{\text {nd }}$ June 2020

\begin{abstract}
How to Cite: Silalahi, D. K., Mukhtar, H., Sari, S. P., Sari, E. A., \& Barus, D. T. (2020). The Effect Analysis of Braden Scale on Pressure Ulcer in Community-Dwelling Older Adults. ComTech: Computer, Mathematics and Engineering Applications, 11(2), 83-88. https://doi.org/10.21512/comtech.v11i2.6237
\end{abstract}

\begin{abstract}
The research aimed to analyze the Braden Scale on the incidence of compressive wounds in elderly people who lived in homes, whether they were or not under the supervision of health workers. The research was analytic with a cross-sectional study. With the purposive sampling technique, the data collection was carried out from several areas in Bandung from October to November 2017. Moreover, the analysis used was multiple regression to see the effect of the Braden Scale on pressure ulcers. The multiple linear regression model was also tested. The results show that $48,22 \%$ of pressure ulcer factors can be influenced by sensory perception, humidity, activity, mobility, nutrition, and friction. Sensory perception, activity and friction have significant influence on incidence of pressure ulcers. Meanwhile, the humidity, mobility, and nutrition do not significantly influence it.
\end{abstract}

Keywords: pressure ulcer, Braden Scale, communitydwelling older adults

\section{INTRODUCTION}

According to Government Regulation of the Republic of Indonesia Number 43 of 2004, an elderly person is someone who has reached the age of 60 years and above. The increase in the number of elderly people in Indonesia is a challenge with positive and negative impacts. It has a positive impact if the elderly population remains healthy, active, and productive. On the contrary, it is a negative impact if there are problems in declining health and income and the absence of social and environmental support for the elderly population. Based on population projection data, the Ministry of Health of the Republic of Indonesia estimates that the number of the elderly population in 2035 will reach 48,19 million, about $15 \%$ of the total population population (Pusat Data dan Informasi Kementerian Kesehatan Republik Indonesia, 2018). According to Adioetomo, Howell, McPherson, and Priebe (2013), the percentage of the number of elderly people in Indonesia is estimated to reach $23 \%$ by 2050 . The data show that Indonesia will enter an era of aging population because the number of the elderly population exceeds 7\% (Sahar, Riasmini, Kusumawati, \& Erawati, 2017). Based on National Socio-Economic Survey data, the percentage of the elderly population above $7 \%$ has existed since 2015 , which is $8,1 \%$.

Biologically, the elderly population will experience a continuous aging process characterized by a decrease in physical endurance so that they are vulnerable to disease that can cause death. Therefore, the elderly population is one of the community groups that need health services the most. The aging factor strongly influences health complaints experienced by elderly people. Based on statistical data on the elderly population, as they get older, their health complaints increase (Pusat Data dan Informasi Kementerian Kesehatan Republik Indonesia, 2018). Nevertheless, the aging process still triggers physical, mental, social, and spiritual changes in elderly people (Chatterji, Byles, Cutler, Seeman, \& Verdes, 2015). It causes an increase in the risk of various health problems (Singh et al., 2018).

One of the indicator used to measure health status is morbidity. According to Statistics Indonesia data in 2017, the morbidity rate for elderly was $26,72 \%$. It could be seen in 2015-2017, the morbidity rate for elderly continued to decrease. However, its degression was relatively small (Badan Pusat Statistik, 2018). The increase in the elderly population brings challenges in the health sector. In community-dwelling older adults, various health problems arise. The target to keep elderly people healthy and active 
became the main focus, as evidenced by more than 3.500 scientific articles discussing healthy and successful aging in 2016 (Michel \& Sadana, 2017).

The problem found in elderly people is pressure ulcers, which decrease life quality (Sulidah \& Susilowati, 2017). Pressure ulcers are injuries in the skin and underlying tissues. Those are usually above the bone protrusion as a result of pressure or a combination of pressure and friction, according to the National Pressure Ulcer Advisory Panel- European Pressure Ulcer Advisory Panel (NPUAPEPUAP) (National Pressure Ulcer Advisory Panel, European Pressure Ulcer Advisory Panel and Pan Pacific Pressure Injury Alliance, 2016). The recent research in Indonesia, precisely in the city of Bandung, shows that most elderly people in the community have one or more health complaints. Only half of them have access to health services. It is found that the incidence of pressure ulcers in elderly people at home is $10,8 \%$. More than half the injuries $(61,4 \%)$ found in respondents are in category 1 injuries and generally in the area around the fingers, ankles, and knees (Sari et al., 2019).

One way to recognize the risk of pressure ulcers is the Braden Scale (Mukhtar, Sari, \& Sari, 2019). It has been tested by reliability and validity using various types of hospitals and patients (Mizan, Rosa, \& Yuniarti, 2016). It consists of six variables. It includes sensory perception, humidity, activity, mobility, nutrition, and friction with the surface of the mattress (Zambonato, Assis, \& Beghetto, 2013). The maximum score on the Braden Scale is 23. Scores above 20 are for low risk, 16-20 for moderate risk, 11-15 for high risk, and less than 10 for very high risk (Cox, 2012).

Pressure ulcer is associated with patient harm and decrease in life quality (Lovegrove, Miles, \& Fulbrook, 2018). Therefore, treating pressure ulcers is the main measure of health service quality. Considering it is largely preventable, it continues occurring in hospitalized patients. Internal prevention in the hospital environment starts from the possible risks and structured and validated tool for considering the risk factors for pressure ulcer patients and risk level (Coleman et al., 2018).

Based on the description above, the research aims to analyze the Braden Scale on the incidence of pressure ulcers in elderly people who live in homes, whether they are under the supervision of health workers or not. The research result is expected to give information about the factors that can significantly influence pressure ulcers in elderly people. Furthermore, the information can provide an insight into how to prevent pressure ulcers.

\section{METHODS}

The research is an analytic study with a cross-sectional approach. The researchers do not take any intervention or special treatment on the subject of research and are limited to collect subject data needed through medical records (Laksmi, Putra, \& Wiranata, 2019). The research uses a purposive sampling technique by taking respondents based on certain characteristics and considerations. Respondents are elderly residents with the criteria of living at home and suffering from pressure ulcers, whether they are under the supervision of a health worker or not. The sample consists of 325 elderly people. However, only 35 elderly people meet the criteria of having pressure ulcers that will be further analyzed.

Data collection is carried out in several areas in
Bandung in one month (October - November 2017) by six nurses who have passed the national nurse competency test. The assessment of pressure ulcers is done by direct observation using the International Prevalence Measurement of Care Quality questionnaire that has been validated in Indonesian (Amir, Kottner, Schols, Lohrmann, \& Halfens, 2014). The categories of pressure ulcers are determined based on the referral standard of NPUAP-EPUAP-Pan Pacific Pressure Injury Alliance (NPUAP-EPUAP-PPPIA). Moreover, the risk factor assessment uses the Braden Scale.

The researchers use regression analysis to analyze the effect of the Braden Scale on the incidence of pressure ulcers in elderly people. It is a data analysis technique in statistics to examine the relationship between several independent variables and predict a dependent variable (Kurtner, Nachtsheim, \& Neter, 2004). For analysis, the independent variable will be stated with $\mathrm{X}$, while the nonindependent variable is expressed as Y. The multiple linear regression model is as follows:

$$
Y=\beta_{0}+\beta_{1} X_{1}+\beta_{2} X_{2}+\cdots+\beta_{i} X_{i}+\varepsilon_{i}
$$

$$
\begin{array}{ll}
\text { Description: } & \\
\beta_{0} & : \text { Dependent variable } \\
\beta_{1}, \beta_{2}, \ldots, \beta_{i} & : \text { intercept } \\
X_{1}, X_{2}, \ldots, X_{i} & : \text { Coefficient of independent variables } \\
\varepsilon_{i} & : \text { independent variable } \\
i & : \text { Index of subject }(\mathrm{i}=1,2, \ldots, \mathrm{n})
\end{array}
$$

The method of regression parameter estimation is ordinary least square. There are several assumptions imposed in the use of multiple linear regression. Some of them assume the normality of error, no multicollinearity, non-autocorrelation, and homoscedasticity. There are several descriptions of the assumption test in regression analysis. First, the normality test in the regression model is used to test whether the residual values generated from the regression are normally distributed or not. A good regression model has a normally distributed residual value (Schmidt \& Finan, 2018). The assumption of normality is carried out using the Kolmogorov-Smirnov test.

Second, there is no multicollinearity. Testing for the presence or absence of multicollinearity symptoms considers the value of the correlation matrix produced during data processing and the value of Variance Inflation Factor (VIF). It is the inflation factor of the standard deviation. The classic multicollinearity assumption test is used to measure the level of association of the relationship between the independent variables through the magnitude of the correlation coefficient (Yu, Jiang, \& Land, 2015). VIF values that are greater than 10 indicate multicollinearity to occur (Stevens, 2009).

Third, for the non-autocorrelation assumption, the Durbin-Watson is used. If autocorrelation occurs, the equation will not be good. The predictable statistical values from the Durbin-Watson test, which is greater than 2 or smaller than -2 , show autocorrelation symptoms (Field, 2013).

Fourth, it is necessary to test the same or different variants of the residuals from one observation to another in multiple regression equation. If residuals have same variance, it is called homoscedasticity. Meanwhile, if it is not, 
it is called heteroskedasticity. A good regression equation happens when heteroskedasticity does not occur (Gujarati, 2004). The heteroskedasticity assumption is conducted using the Levene test by regressing the independent variable with the absolute value of the residual. If the significance value between the independent variables and absolute residuals is more than 0,05 , there is no heteroscedasticity problem.

In this research, multiple linear regression analysis determines the effect of Braden Scale on the incidence of pressure ulcers. It analyzes statistically the effect of parameters measured based on the Braden Scale on pressure sores with subjects in the elderly community. It shows whether there is the influence of the independent variable on the dependent variable simultaneously and partially or not. To test the suitability of the regression model simultaneously, the researchers use F-test at the significance level of $\alpha=0,05$. Meanwhile, for the significance of the regression coefficients individually (partial), the researchers utilize the t-test at the significance level of $\alpha=0,05$.

Moreover, the coefficient of determination $\left(\mathrm{R}^{2}\right)$ is conducted to see whether there is a perfect relationship or not. It is indicated by whether the dependent variable will follow the change in the independent variable in the same proportion. This test is done by looking at the value of
$\mathrm{R}$-squared $\left(\mathrm{R}^{2}\right)$. The coefficient of determination is between 0 and 1 . The whole analysis uses the help of STATCAL software (Gio \& Caraka, 2018).

\section{RESULTS AND DISCUSSIONS}

The characteristics of respondents consist of age, gender, and status of residence. Those are categorized based on the Braden Scale assessment, as shown in Table 1. Meanwhile, the Braden Scale assessment based on the severity of the injuries is presented in Table 2.

Based on Table 1, the pressure ulcer is generally found in elderly people aged above 70 years. Mostly, it occurs in women with $57,1 \%$. Seeing the status of residence in community-dwelling older adults, there are various results. However, most of them still live with their extended families around $63 \%$. It is followed by the status of living with a spouse and/or child with $17 \%$.

Furthermore, from the characteristics of the collected data, a Braden Scale assessment is based on the severity of the injuries. A health professional does it by examining the severity of the wound. Then, they categorize the severity of the wound based on standardized guidelines. The Braden Scale assessment is presented in Table 2.

Table 1 The Characteristics of Respondents

\begin{tabular}{|c|c|c|c|c|c|c|c|}
\hline \multirow[b]{2}{*}{$\begin{array}{l}\text { Characteristics of } \\
\text { Respondents }\end{array}$} & \multicolumn{6}{|c|}{ Pressure Ulcer Category (PU Cat) } & \multirow[b]{2}{*}{ Total $(n=35)$} \\
\hline & $\begin{array}{c}\text { PU Cat } 1 \\
(n=18)\end{array}$ & $\begin{array}{l}\text { PU Cat } 2 \\
\quad(n=5)\end{array}$ & $\begin{array}{c}\text { PU Cat } 3 \\
\quad(n=9)\end{array}$ & $\begin{array}{l}\text { PU Cat } \\
4(n=0)\end{array}$ & $\begin{array}{c}\text { Unstageable } \\
(\mathbf{n}=\mathbf{0})\end{array}$ & $\begin{array}{c}\text { Suspended Deep } \\
\text { Tissue Injury } \\
(n=3)\end{array}$ & \\
\hline Age, year (Mean/SD) & $73,7(8,5)$ & $74(1,7)$ & $78,5(8,2)$ & - & - & $\begin{array}{l}77,7 \\
(8,4)\end{array}$ & $\begin{array}{l}74,8 \\
(7,8)\end{array}$ \\
\hline Female, n (\%) & $12(66,7 \%)$ & $3(60 \%)$ & $5(55,6 \%)$ & - & - & $0(0 \%)$ & $20(57,1 \%)$ \\
\hline \multicolumn{8}{|l|}{ Status of residence, $\mathrm{n}(\%)$} \\
\hline a. Own & $2(11,1 \%)$ & $0(0 \%)$ & $1(11,1 \%)$ & - & - & $0(0 \%)$ & $3(9 \%)$ \\
\hline b. With spouse & $3(16,7 \%)$ & $0(0 \%)$ & $0(0 \%)$ & - & - & $1(33,3 \%)$ & $4(11 \%)$ \\
\hline $\begin{array}{l}\text { c. With spouse and/or } \\
\text { children }\end{array}$ & $3(16,7 \%)$ & $2(40 \%)$ & $1(11,1 \%)$ & - & - & $0(0 \%)$ & $6(17 \%)$ \\
\hline d. Extended family & $10(55,6 \%)$ & $3(60 \%)$ & $7(77,8 \%)$ & - & - & $2(66,7 \%)$ & $22(63 \%)$ \\
\hline
\end{tabular}

Note: PU Cat 1: Category I - non-blanchable erythema; PU Cat 2: Category II - partial thickness skin loss; PU Cat 1: Category III - fullthickness skin loss; and PU Cat 4: Category IV - full-thickness tissue loss.

Table 2. Braden Scale Assessment

\begin{tabular}{lccccccc}
\hline \multirow{2}{*}{$\begin{array}{c}\text { Braden Scale } \\
\text { (item, mean) } \\
\mathbf{( S D )}\end{array}$} & $\begin{array}{c}\text { PU Cat 1 } \\
(\mathbf{n}=\mathbf{1 8})\end{array}$ & $\begin{array}{c}\text { PU Cat } \mathbf{2} \\
\mathbf{( n = 5 )}\end{array}$ & $\begin{array}{c}\text { PU Cat 3 } \\
\mathbf{( n = 9 )}\end{array}$ & $\begin{array}{c}\text { PU Cat 4 } \\
(\mathbf{n}=\mathbf{0})\end{array}$ & $\begin{array}{c}\text { Unstageable } \\
(\mathbf{n}=\mathbf{0})\end{array}$ & $\begin{array}{c}\text { Suspended Deep } \\
\text { Tissue Injury (n=3) }\end{array}$ & Total (n=35) \\
\hline Sensory perception & $3,5(0,7)$ & $3,3(1,2)$ & $3,3(0,5)$ & - & - & $3,7(0,6)$ & $3,1(0,8)$ \\
Humidity & $3,2(0,4)$ & $2,7(0,6)$ & $3(0)$ & - & - & $3(0)$ & $3(0,6)$ \\
Activity & $3,1(0,8)$ & $2,7(1,5)$ & $3(0,6)$ & - & - & $2,3(0,6)$ & $2,4(1)$ \\
Mobility & $3,5(0,9)$ & $2,7(1,5)$ & $3,2(0,8)$ & - & - & $2,3(0,6)$ & $2,6(1,1)$ \\
Nutrition & $3,6(0,7)$ & $3,7(0,6)$ & $4(0)$ & - & - & $3(1)$ & $3,4(0,8)$ \\
Friction & $2,8(0,6)$ & $2,3(1,2)$ & $3(0)$ & - & - & $2,7(0,6)$ & $2,4(0,8)$ \\
\hline
\end{tabular}


Before inferencing the regression model, the regression analysis assumptions are tested. First, it is the normality test. Testing for normality at $5 \%$ confidence level $(\alpha=0,05)$ obtains greater $p$-value than $\alpha=0,05$ which is 0,40335 . Hence, the normality assumption decision is obtained. The statistics value of Kolmogorov-Smirnov $(0,15084)$ is smaller than the value of the KolmogorovSmirnov table $(0,23)$. Thus, the same decision is also obtained that the assumption of normality is met.

Second, the test for the assumptions that multicollinearity does not occur is presented in Table 3 by looking at the VIF value. From Table 3, the VIF value for each variable is less than 10 . The variables are free from multicollinearity. Thus, the assumption of no multicollinearity is fulfilled. It means that between independent variables, multicollinearity does not occur.

Table 3 Variance Inflation Factor (VIF) Value of the Independent Variables

\begin{tabular}{lc}
\hline \multicolumn{1}{c}{ Variables } & VIF \\
\hline Sensory perception & 1,986844 \\
Humidity & 1,550837 \\
Activity & 9,003071 \\
Mobility & 7,573989 \\
Nutrition & 1,932357 \\
Friction & 3,636482 \\
\hline
\end{tabular}

Third, the researchers test the assumption of nonautocorrelation by calculating the statistical value of the Durbin-Watson. The result is 0,24575. Therefore, the statistical value of the Durbin-Watson test is at an interval of $-2 \leq 0,24575 \leq 2$. There is no autocorrelation.

Fourth, it is the assumption of homoscedasticity. From Table 4, the p-value is more than 0,05 . If the significance is more than 0,05 , there is no heteroscedasticity in the regression model. It implies that the distribution of dependent and independent variables spread below and above the Y-axis and do not have a regular pattern. It can be concluded that in the independent variables, there is no heteroskedasticity. It means that the assumption of homoscedasticity is fulfilled. Thus, the variance of the error is constant.
Table 4 The Test of the Assumption of Homoscedasticity

\begin{tabular}{lcc}
\hline & Statistic Test & P-Value \\
\hline Levene & 0,61 & 0,626 \\
\hline
\end{tabular}

After testing the classical assumptions in multiple linear regression, the researchers conclude that the classical assumption test is fulfilled. The assumptions of normality, no multicollinearity, non-autocorrelation, and homoscedasticity are met. Thus, the obtained multiple linear regression model is good and feasible.

Next, the simultaneous regression model test determines whether there is a significant influence between sensory perception, humidity, activity, mobility, nutrition, and friction on pressure ulcers. Based on the results of the F-test, the obtained statistical F-value is 0,8122 . The value is greater than the F-table. Hence, there is simultaneous significant influence between sensory perception, humidity, activity, mobility, nutrition, and friction on the incidence of pressure ulcers. The significant test of the regression coefficients individually is also carried out using the t-test (see Table 5). The data are obtained from the following regression models:

$$
\begin{aligned}
& Y=1,99+1,613 X_{1}-0,473 X_{2}-1,732 X_{3}-0,106 X_{4}- \\
& 0,874 X_{5}+1,059 X_{6}
\end{aligned}
$$

Description:

$\mathrm{Y}=$ Pressure ulcer

$\mathrm{X}_{1}=$ Sensory perception

$\mathrm{X}_{2}=$ Humidity

$\mathrm{X}_{3}=$ Activity

$\mathrm{X}_{4}=$ Mobility

$\mathrm{X}_{5}=$ Nutrition

$\mathrm{X}_{6}=$ Friction

Based on the data presented in Table 5, the results of regression analysis results can be explained. The regression coefficient value of the sensory perception variable is positive $(1,613)$. It means that the sensory perception of the Braden Scale positively influences pressure ulcers. In addition, the p-value is smaller than the 0,05 . Thus, the pressure ulcer is significantly influenced by sensory perception.

Moreover, the regression coefficient value of the activity is $-1,732$, and the $p$-value is smaller than 0,05 . It means activity affects pressure ulcers. Furthermore, the regression coefficient value of the friction is also positive,

Table 5 The Regression Analysis Results

\begin{tabular}{lcccc}
\hline \multicolumn{1}{c}{ Braden Scale Factor } & Estimation & Standard Error & t-Value & p-Value \\
\hline (Intercept) & 1,99 & 1,84 & 1,09 & 0,287 \\
Sensory perception & 1,613 & 0,452 & 3,57 & 0,001 \\
Humidity & $-0,473$ & 0,519 & $-0,91$ & 0,370 \\
Activity & $-1,732$ & 0,718 & 2,41 & 0,023 \\
Mobility & 0,106 & 0,627 & 0,17 & 0,867 \\
Nutrition & $-0,874$ & 0,426 & $-2,05$ & 0,05 \\
Friction & 1,509 & 0,607 & 2,49 & 0,019 \\
\hline
\end{tabular}


which is 1,509 . Moreover, the p-value is smaller than 0,05 . Hence, friction affects pressure ulcers. On the other hand, other variables such as humidity, mobility, and nutrition have a more significant p-value than 0,05 . It means they do not affect pressure ulcers.

Based on Table 5, besides p-value, t-value can also determine which variables have a significant effect on pressure ulcers. By comparing t-value and t-table with mean degrees of freedom $(\alpha ; n-k-1$ or 0,$05 ; 35-6-1)$, t-table is 2,0481. In Table 5, sensory perception, activity, and friction have a greater $\mathrm{t}$-value than t-table. Hence, they have a significant effect on ulcer pressure. On the other hand, humidity, mobility, and nutrition have a smaller t-value than $\mathrm{t}$-table, so that they have no significant effect.

Moreover, the standard error of the variable indicates the deviation of the regression coefficient in the variables. The smaller deviation in the regression coefficient means a more significant contribution of its variables. Based on Table 5, the smallest standard error is in sensory perception. It shows that sensory perception has the smallest deviation in the regression coefficient. It implies that the contribution of sensory perception is very significant to pressure ulcers.

Next, the determinant coefficient test shows whether there is a perfect relationship with changes in the independent variable, followed by the dependent variable in the same proportion. The results of the determinant coefficient obtained are $48,22 \%$. It shows that the relationship between sensory perception, humidity, activity, mobility, nutrition, and friction simultaneously on pressure ulcer is equal to $48,22 \%$. Meanwhile, the remaining around $51,78 \%$ is caused by other factors not examined in the research.

Data processing and analysis results using regression analysis in the research show that sensory perception, activity, and friction influence pressure ulcers in communitydwelling older adults. The research result is similar to Mukhtar et al. (2019) by using Pearson correlation. They mentioned that activity, mobility, and friction affected the incidence and severity of pressure ulcers in elderly people. Thus, the two analytical methods conclude that the activity and friction influence the occurrence of pressure ulcers. Therefore, elderly people who live at home need to consider their activities that cause the risk of friction on their skin, such as praying, sitting cross-legged on the floor that is not covered with comfortable material, sleeping positions for long periods, and others.

The analysis results are also in line with previous research that the estimated number of category 1 in pressure ulcers in elderly people in the community is associated with praying habits such as prostration and sitting cross-legged (Sari et al., 2019). The research proves that the sensory perception felt by elderly people is closely related to the friction on the surface of their skin. Therefore, elderly people who live in the community must pay attention to their skin to reduce the friction by using tools and taking care of the skin that already has pressure ulcers due to repeated friction.

On the other hand, the research shows a low relationship between mobility, humidity, and nutrition with the severity of ulcers in elderly people in the community. However, these results do not necessarily prove that these factors do not affect pressure ulcers. It is also in line with the results of previous studies conducted. Mukhtar et al. (2019) agreed that the dominant factors that influenced the severity of pressure on elderly people in the community were activity, mobility, and friction. Conversely, friction, and nutrition had the lowest relationship with the severity of pressure ulcers. The interaction of friction with activity and mobility factors greatly influenced the emergence of pressure ulcers.

\section{CONCLUSIONS}

The researchers collect data from several regions in Bandung on 325 elderly people living in communities, with 35 of them having pressure ulcers. Research results based on the Braden Scale show that sensory perception, activity, and friction significantly affect pressure ulcers. Meanwhile, humidity, mobility, and nutrition have no significant effect on ulcer pressure. These results are based on the applied multiple regression analysis. Furthermore, the determinant coefficient obtained is $48,22 \%$. Hence, the relationship of sensory perception, humidity, activity, mobility, nutrition, and friction with pressure ulcers is $48,22 \%$ simultaneously. Meanwhile, the remaining $(51,78 \%)$ is caused by other factors which are not examined in the research. The next research that can be applied is the severity prediction of pressure ulcers based on the Braden Scale using prediction methods in data mining, such as the Support Vector Machine.

\section{REFERENCES}

Adioetomo, S. M., Howell, F., McPherson, A., \& Priebe, J. (2013). Social assistance for the elderly in Indonesia: An empirical assessment of the Asistensi Sosial Lanjut Usia Terlantar programme. Indonesia - National Team for the Acceleration of Poverty Reduction, TNP2K

Amir, Y., Kottner, J., Schols, J. M. G. A., Lohrmann, C., \& Halfens, R. J. G. (2014). Psychometric properties of the Dutch national prevalence measurement of care problems used to measure quality of pressure ulcer care in Indonesian hospitals. Advances in Skin \& Wound Care, 27(8), 363-370. https://doi. org/10.1097/01.ASW.0000452044.58375.43

Badan Pusat Statistik. (2018). Statistik penduduk lanjut usia 2017. Retrieved from https://www.bps.go.id/ publication/2018/04/13/7a130a22aa29cc8219c5d1 53statistik-penduduk-lanjut-usia-2017.html.

Chatterji, S., Byles, J., Cutler, D., Seeman, T., \& Verdes, E. (2015). Health, functioning, and disability in older adults - Present status and future implications. The Lancet, 385(9967), 563-575. https://doi.org/10.1016/ S0140-6736(14)61462-8

Coleman, S., Smith, I. L., McGinnis, E., Keen, J., Muir, D., Wilson, L., ... \& Nixon, J. (2018). Clinical evaluation of a new pressure ulcer risk assessment instrument, the Pressure Ulcer Risk Primary or Secondary Evaluation Tool (PURPOSE T). Journal of Advanced Nursing, 74(2), 407-424. https://doi. org/10.1111/jan.13444

Cox, J. (2012). Predictive power of the Braden Scale for pressure sore risk in adult critical care patients: A comprehensive review. Journal of Wound, Ostomy and Continence Nursing, 39(6), 613-621. https://doi. org/10.1097/WON.0b013e31826a4d83

Field, A. (2013). Discovering statistics using IBM SPSS Statistics $\left(4^{\text {th }}\right.$ ed.). SAGE Publication Ltd. 
Gujarati, D. N. (2004). Basic econometrics (4th ed.). McGraw-Hill Companies.

Kurtner, M. H., Nachtsheim, C., \& Neter, J. (2004). Applied linear regression models (4 ${ }^{\text {th }}$ ed.). McGraw-Hill/ Irwin.

Laksmi, I. A. A., Putra, P. W. K., \& Wiranata, I. K. (2019). Studi korelasi antara BMI dengan mortalitas pasien gagal jantung kongestif. Gaster, 17(1), 11-19. https://doi.org/10.30787/gaster.v17i1.343

Lovegrove, J., Miles, S., \& Fulbrook, P. (2018). The relationship between pressure ulcer risk assessment and preventative interventions: A systematic review. Journal of Wound Care, 27(12), 862-875. https://doi. org/10.12968/jowc.2018.27.12.862

Michel, J. P., \& Sadana, R. (2017). "Healthy aging" concepts and measures. Journal of the American Medical Directors Association, 18(6), 460-464. https://doi. org/10.1016/j.jamda.2017.03.008

Mizan, D. M., Rosa, E. M., \& Yuniarti, F. A. (2016). Perbandingan skala Braden dan skala Gosnell dalam menilai tingkat resiko luka tekan. In Prosiding Interdisciplinary Postgraduate Student Conference $1^{\text {st }}$ Program Pascasarjana Universitas Muhammadiyah Yogyakarta (pp. 259-263).

Mukhtar, H., Sari, S. P., \& Sari, E. A. (2019). Faktor risiko yang mempengaruhi tingkat keparahan luka tekan pada lansia di masyarakat. Journal of Health Science and Prevention, 3(1), 32-38. https://doi. org/10.29080/jhsp.v3i1.187

National Pressure Ulcer Advisory Panel, European Pressure Ulcer Advisory Panel and Pan Pacific Pressure Injury Alliance. (2016). Prevention and Treatment of Pressure Ulcers: Quick Reference Guide. Retrieved from https://www.epuap.org/wpcontent/uploads/2016/10/quick-reference-guidedigital-npuap-epuap-pppia-jan2016.pdf

Pusat Data dan Informasi Kementerian Kesehatan Republik Indonesia. (2018). Analisis lansia di Indonesia 2017. Retrieved from https://pusdatin.kemkes. go.id/article/view/18012600001/analisis-lansia-diindonesia-2017.html
Sahar, J., Riasmini, N. M., Kusumawati, D. N., \& Erawati, E. (2017). Improved health status and life satisfaction among older people following self-help group intervention in Jakarta. Current Gerontology and Geriatrics Research, 2017, 1-7. https://doi. org/10.1155/2017/3879067

Sari, S. P., Everink, I. H., Sari, E. A., Afriandi, I., Amir, Y., Lohrmann, C., ... \& Schols, J. M. (2019). The prevalence of pressure ulcers in communitydwelling older adults: A study in an Indonesian city. International Wound Journal, 16(2), 534-541. https://doi.org/10.1111/iwj.13081

Schmidt, A. F., \& Finan, C. (2018). Linear regression and the normality assumption. Journal of Clinical Epidemiology, 98, 146-151. https://doi. org/10.1016/j.jclinepi.2017.12.006

Singh, N. S., Bass, J., Sumbadze, N., Rebok, G., Perrin, P., Paichadze, N., \& Robinson, W. C. (2018). Identifying mental health problems and idioms of distress among older adult internally displaced persons in Georgia. Social Science \& Medicine, 211(August), 39-47. https://doi.org/10.1016/j.socscimed.2018.05.007

Stevens, J. P. (2009). Applied multivariate statistics for the social sciences $\left(5^{\text {th }}\right.$ ed.). Routledge/Taylor \& Francis Group.

Sulidah, \& Susilowati. (2017). Pengaruh tindakan pencegahan terhadap kejadian dekubitus pada lansia imobilisasi. MEDISAINS: Jurnal Ilmiah Ilmu-Ilmu Kesehatan, 15(3), 161-172.

Gio, P. U., \& Caraka, R. E. (2018). Pedoman dasar mengolah data dengan program aplikasi statistika STATCAL (Disertai perbandingan hasil dengan SPSS \& Minitab). USU Press.

Yu, H., Jiang, S., \& Land, K. C. (2015). Multicollinearity in hierarchical linear models. Social Science Research, 53(September), 118-136. https://doi.org/10.1016/j. ssresearch.2015.04.008

Zambonato, B. P., Assis, M. C. S. D., \& Beghetto, M. G. (2013). Association of Braden subscales with the risk of development of pressure ulcer. Revista Gaucha de Enfermagem, 34(2), 21-28. https://doi.org/10.1590/ S1983-14472013000200003 